\title{
Smart Start-A Survival Guide for First Year College Students (And Their Parents Too)
}

\author{
CD-ROM \\ By College Sunvival Guides \\ Published by National Tape and Disc Corporation, Nashville, TN, 2004 \\ Reviewed by Dr. Melinda K. Dalgarn \\ College Survival Guides
}

Smart Start is an honest look at the many issues that confront first-year college students. The $C D$ offers a straight-forward, comprehensive glimpse at life on campus. The presentation is bright, clever, colorful, and altractive. Easy to navigate, the reader can move from one chapter to another (through all 13), access embedded files, or jump right to the appendix that includes the Greek alphabet, a financial management worksheet, a list of things to bring (and leave at home), and even a four-year career development checklist. Each chapter concludes with three thought-provoking questions designed to encourage conversation with parents, faculty, staff, or peer advisers. The author's advice and campus experience make Smart Siart an important source of information for new students (and their parents too).

Smart Start provides students and parents with an accurate sense of the journey upon which they are embarking by describing the complex challenges and opportunities that accompany students" newfound freedom. Distinctions are made between high school and college and students are challenged to assume increased personal responsibility. Although the author acknowledged that there is a lot to learn in a relatively short period of time, she also assured new students that there are support systems in place to help them mavigale these uncharted walers. Open cummunication, use of a daily planner, campus involvement, a positive attitude, and realistic expectations are just some of the suggestions provided as students transition from high school to college.

Not unexpectedly, Smart Start's initial emphasis is on setting academic prioritics. Success in college is said to be determined by motivation, dedication, and an ability to manage time. The importance of establishing relationships with faculty is emphasized and students are encouraged to meet with faculty advisers on a regular basis, prepared with some questions to ask and others to answer.

Note taking techniques, time and environmental management, the importance of establishing a routine, color-coded calendars, the value of a "to do" list, test taking tips, the "major" question, and the value of international study are all discussed in derail. Students learn that they are held accountable for their behavior both inside and outside the classroom. The meaning of academic integrity and codes of conduct is made clear and judicial sanctions are discussed and brief explanations of sanctions are provided.

While it is clear that academics are the first priority, the author emphasizes that lessons learned in college will not all occur in the classroom. Data were presented that 
suggest that students who live on campus earn better grades, are more fully engaged in campus life, interact more frequently with faculty and staff, and are more satisfied with their college experience than those who do not.

Being able to manage the demands of campus life inside and outside the classroom requires that students maintain some semblance of healthy living. The $\mathrm{CD}$ provides the suggestion that feeling well, being well, and doing well are dependent on students' ability to eat properly and get adequate amounts of sleep and exercise-

With statistics suggesting that as many as $25 \%$ of all college women suffer from some form of eating disorder, anorexia and bulimia are discussed at length. The warning signs of stress and depression are also described as are methods or treatments for managing each. Health issues related to meningococcal meningitis, contraceptive protection, STDs and HTV are also mentioned.

The use and abuse of alcohol and drugs are introduced very effectively with a series of staggering statistics. Data presented indicate that students spend $\$ 5.5$ billion on alcohol each year. That is more than they spend on books, soft drinks, coffee, juice, and milk combined. Important distinctions are made between the "social drinker" and the "problem drinker" and characteristics of each are provided. In addition, "substance addiction" is distinguished from "activity addiction;" those addictions associated with activities such as gambling, shoplifting, and excessive use of the Internet, found to be ever-increasing activities on college campuses.

In addition to time management, first year students must also leam to manage money. Credit costs including finance charges, annual percentage rates, annual fees, and application fees are deseribed. Other topies include the responsible use of credit cards, income vs. expenses, and the warning signs of financial trouble. Important tips for avoiding identity theft are deseribed and specific information that includes web sites and credit reporting agency contacts are provided in case students do become victims of theft.

Safety tips are provided and students are challenged to accept personal responsibility for assisting in the maintenance of a secure campus. Students are encouraged to use common sense when moving about the campus. Locking room dours, traveling in groups after dark, and avoiding the urge to study in vacant classrooms are essential to the salety and well-being of members of the college community. With 1700 fires in campus residence halls and Greek facilities each year, fire safety tips are provided as well. Issues of rape and sexual assault are also addressed.

The CD-ROM also provides the recommendation that new students begin building resumes their first year. They should be able to articulate three things: what they enjoy doing. what they are good at doing, and what kinds of rewards provide them with the greatest satisfaction. Students are encouraged to develop skills and gain experience through internships, extracurricular involvement, and service learning programs. Students are also encouraged to take advantage of services provided by campus career centers. These most often include interest inventories, resume writing, and interview advice as well as job fairs and alumni networks. Knowing how interests intersect with aspirations can be helpful as one moves through the career process. 
Sman Sron dedicales a chapict to tixose fist yeirs students who live of:-campus and re-ogmizes the unique challenges and upportunitics with which they must contend. Mnst assume dual soles as audentemplovoc. sadenuzareal ur studentiesregiver. Inaser of part:ng. where 10 spend äme ietween elawes, snd even child care can be a daily challenge. Connuters sre encouragod wo sei involved on campers es the extent allowed by their schedules. 20 establish relatiurschips with focuity and staff that will prove helpful wben sefcreaces are needed, and to ideanfy the custact posson on campus utro is a commuser sd sacase.

For those l(x)king for a quick lis: of tips, the firal chapier is a compilation of helpful advice from eurrens collese stuxtents, parens, feculty, seaft and fanour fulks throughour history. Their uurds of wisdom arc sometimes light-heared, ofien aspure. and sluisys well. intentinned. 